\title{
Carabid beetle assemblages in three environments in the Araucaria humid forest of southern Brazil
}

\author{
Rodrigo Milton Moraes ${ }^{1,2}$, Milton de Souza Mendonça $\mathrm{Jr}^{1}$ \& Ricardo Ott ${ }^{2}$
}

\author{
'Laboratório de Ecologia de Interações, Departamento de Ecologia, Instituto de Biologia, Universidade Federal do Rio Grande do Sul, Av. Bento \\ Gonçalves, 9500, 91501-970 Porto Alegre-RS, Brazil. milton.mendonca@ufrgs.br \\ ${ }^{2}$ Museu de Ciências Naturais, Fundação Zoobotânica do Rio Grande do Sul, Av. Salvador França, 1427, 90690-000 Porto Alegre-RS, Brazil. \\ rodrigao.mmoraes@gmail.com
}

\begin{abstract}
Carabid beetle assemblages in three environments in the Araucaria humid forest of southern Brazil. Carabidae is composed mainly by ground-dwelling predator beetles. It is the fourth most diverse group within Coleoptera, but its diversity in the Neotropical region is understudied. Here we describe and analyze the diversity of carabid beetles in a region of subtropical rain forest dominated by Araucaria angustifolia with different landscapes. Three areas were chosen in an environmental integrity gradient: primary forests, secondary forests and old Pinus plantations. Pitfall traps were taken monthly, in a total of 14 samples per area. 1733 adult carabid beetles, belonging to 18 species, were sampled. There were differences in richness and abundance between the sampled areas. The total scores followed the same tendency: primary forests (14 species/747 individuals), secondary forests (13/ 631) and Pinus forests (10/355). An analysis of similarity shows differences in species composition, for both areas and seasons. Galerita lacordarei was the most abundant species for all samples and seasons. Carabid species show similar responses in accordance with habitat heterogeneity and disturbance. The abundance of Galerita lacordarei was influenced by temperature, for all sampled sites. Environmental changes affect the carabid assemblages and decrease diversity, possibly interfering in local dynamics. Seasonality patterns seem to indicate an increase in individual movement during summer, probably in search of resources. It is suggested that microhabitat patchiness is probably an important factor affecting carabid beetle diversity at small spatial scales.
\end{abstract}

KEYWORDS. Carabidae; Coleoptera; diversity; Insecta; pitfall trap.

Carabids are typical soil beetles, usually found on sandy terrain, under rocks and litter (Triplehorn \& Johnson 2005), but some groups inhabit trees and shrubs (Erwin 2000). According to Marinoni et al. (2001) and Marinoni (2001), carabids are included in the carnivore trophic group given their predatory character. However, some are specialised in feeding on fruits and seeds (Paarmann et al. 2001, 2002).

This family is estimated to be the fourth largest group in Coleoptera, with approximately 40,000 species (Bouchard et al. 2009). In the Neotropical region, Reichardt (1979) estimated 4,400 species grouped in 330 genera and Roig-Juñent (1998) put these numbers at 194 genera for Brazil. Reichardt (1977) cited for Brazil the greatest part of the known carabid richness for the Neotropics, mainly concentrated in the tropical forests (Arndt et al. 2005). This information can only bring an approximation given the present lack of carabid specialists and the historically conflicting taxonomy of this group especially for the tropics (Ball 1996).

Studies in carabids have addressed their diversity through distinct themes: successional stages (Tyler 2008; Magura et al. 2003; Humphrey et al. 1999); fragmentation and urbanisation (Fujita et al. 2008; Hartley et al. 2007; Lövei et al. 2003); disturbance gradients (Silva et al. 2008); responses to environmental characteristics (Uehara-Prado et al. 2009; Schreiner \& Irmler 2009; Latty et al. 2006; Fernández \& Costas 2004; Larsen \& Work 2003; Werner \& Raffa 2000); regeneration in natural areas (Ings \& Hartley 1999) and agroecosystems (Thomas et al. 2006; Boivin \& Hance 2002; Melnychuk et al. 2003; Jukes et al. 2001; Holland \& Luff 2000; Tonhasca 1994). Some of these studies relate the carabid fauna to environmental variables (e.g. temperature, rainfall, canopy cover, soil organic matter content, etc). Nevertheless, we do not know which of these variables best correlate to observed patterns of richness and abundance (Niemelä 1996) and which are more informative at a certain scale and/or situation (e.g. preserved $\mathrm{x}$ altered environments).

Work on the diversity and dynamics of carabid assemblages show clear trends. Although heterogeneous environments have higher diversity and abundance (Fujita et al. 2008; Hartley et al. 2007; Magura et al. 2003; Butterfield 1997), when the carabid fauna is compared between undisturbed and disturbed environments, richness appears to be higher in the latter. This can be a consequence of generalist species emigrating from open areas, given the appropriate conditions created by disturbance (Latty et al. 2006). In some of these cases, abundance can be also higher (Uehara-Prado et al. 2009). Carabid species composition changes under structural changes of the habitat (Scott \& Anderson 2003), being perhaps one of the most informative ways of studying faunal variations (Penev 1996). Some subtropical assemblages seem to have at least one dominant species (Moura 2007), sometimes varying among environments (Werner \& Raffa 2000). Within habitat, small-scale influences (e.g. "patchiness"), are cited as determinant for the local diversity of Carabidae (Schreiner \& Irmler 2009). 
Carabids are increasingly being used as bioindicators of environmental integrity. Taylor \& Dorann (2001), for example, suggest monitoring the effectiveness of restoring altered areas using this group as indicator. In order to foster and widen such uses it is important to understand the patterns shown by carabid populations in differing environments of the Neotropical region. Thus it is necessary to couple biological and ecological work on this group. Bohac (1999) also suggests that studying carabids along with other edaphic arthropods (as staphilinids and arachnids) would enhance our knowledge on soil responses to human change. This has been done in Europe (Desender et al. 1991) and North America (Rainio \& Niemelä 2003; Brown 1997; Eyre et al. 1996), but again such studies are lacking in the Neotropics so far.

Among researches using coleopterans for biodiversity studies in the Neotropics, few consider the Carabidae family alone. Sampling in South America by Erwin (1990), Lucky et al. (2002) and Erwin et al. (2005) investigated the diversity of forest canopy carabids in the Amazon. The latter two studies highlight the strong influence that microhabitats can have on the carabidofauna. Erwin (1990) describes the characteristics composing such microhabitats and emphasises the importance of environmental complexity for carabid diversity.

Studies developed in Brazil include those of Adis et al. (1986, 1990, 1997), gathering data on the diversity and biology of carabids in the Amazon; Vieira (2008) examined forest fragments in the Pantanal; Martins et al. (2009) investigated carabid population fluctuations in an agroecosystem at the interface between crops of soybean and of maize. Aspects of the Amazonian carabid guilds dynamics were also described by Paarmann et al. $(2001,2002)$.

Experiments in exotic silviculture reveal a low diversity for carabids (Holtz et al. 2001), without significant change across seasons in the subtropics (Soares \& Costa 2001). Some implications of the presence of silviculture environments on the beetle fauna in southern Brazil are discussed in Ganho \& Marinoni (2006) (for other predatory invertebrate group (arachnids) see Baldissera et al. 2008).

The diversity of carabid beetles in Rio Grande do Sul state is little explored except for Diefenbach \& Becker (1992a, b), which sampled an urban park with pitfalls, especially in places covered with exotic ivy (Hedera helix, Araliaceae). This last work revealed a seasonal cycle for carabids species in this region. Moura (2007) considered the diversity of carabids among regions of the coastal plain.

Our aim is to compare the diversity of carabid assemblages among distinct forest formations (both natural and artificial) in the Araucaria humid forest ecoregion, Rio Grande do Sul state, also investigating the influence that temperature and rainfall can have on this fauna.

\section{MATERIAL E METHODS}

Sampling took place at the Centro de Pesquisa e Conservação da Natureza Pró-Mata, in São Francisco de Paula municipality, Rio Grande do Sul, in southern Brazil. This privately maintained conservation unit is at a crossroads between the Basaltic Highlands and Coastal Plain regions, in an area of considerable rainfall (annual average higher than 1,800 mm). The average annual temperature is $16^{\circ} \mathrm{C}$, with average maximum and minimum at $27^{\circ} \mathrm{C}$ and $6^{\circ} \mathrm{C}$, respectively. Jungblut \& Pinto (1997) highlight the soil humidity as a function of continuous rains, with no dry season.

Three forest environments were chosen for comparison: primary forest, secondary forest and an area under silviculture with Pinus spp. The primary forest has a predominance of Araucaria angustifolia (Bertol.) Kuntze composing the top canopy layer, the tree stratum is high, with a shrub stratum formed by smaller trees and sparse bamboo clumps. The secondary forest has an abundance of Tibouchina sellowiana (Cham.) Cogn, the shrub layer is less expressive, and bamboo clumps are very frequent. Silviculture areas maintain populations of exotic Pinus taeda L. and Pinus elliotti Engelm. planted decades ago, which explains the presence of a shrub layer composed of young native trees besides its characteristic and compact litter. These environments represent a disturbance gradient: the primary forest has been minimally disturbed, the secondary forest historically suffered some disturbance due to selective logging and Pinus spp. silviculture areas are highly disturbed, although a long time has passed allowing a partial recovery of the local flora and fauna.

Each environment had two replicate sampling sites, each site receiving 10 pitfall traps, $10 \mathrm{~m}$ far from each other and organized in two transects. The trap was built from a $500 \mathrm{ml}$ plastic cup (10 cm diameter, $15 \mathrm{~cm}$ depth). Traps were covered $10 \mathrm{~cm}$ above the cup border to avoid overflowing with rain. Preserving liquid was formaldehyde $4 \%$ with added detergent drops to reduce surface tension. Traps were removed and changed every 30 days, operating from February 2001 until April 2002. Fourteen samples were obtained per site.

The carabid specimens were sorted out from samples carried out in the study of Ott (2004), with the remaining material being stored in Museu de Ciências Naturais, FZB-RS. The carabid beetles were identified with help of taxonomic sources (Reichardt 1967, 1977). A reference collection was established with specimens deposited at "Museu de Ciências Naturais" of FZB-RS, Porto Alegre, documented through digital images.

Environments and climatic seasons were the two factors used in statistical analysis. To test for differences in species richness (species density sensu Gotelli \& Colwell 2001), sample-based rarefactions for the two factors were implemented in PASt software (Hammer et al. 2001). To test for the effect distance between sampling areas has over the composition of the carabid fauna a Mantel test was used, confronting a geographical between-transect distance matrix with a composition similarity matrix (both Simpson and Morisita indexes, also in PASt). To compare three related diversity variables simultaneously (abundance, species richness and equitability) we employed a two-factor MANOVA in SPSS 16.0. Species composition was tested with four ANOSIM (Analysis of Similarity) tests, for both factors and two similarity indexes, a qualitative (Simpson) and a quantitative one 
(Bray-Curtis), calculated with PASt. Abiotic factors were evaluated, with temperature and rainfall tested against carabid species richness and abundance through two multiple regressions using SPSS 16.0. Local temperature and rainfall were obtained from the $8^{\text {th }}$ Meteorological District, in Porto Alegre, Rio Grande do Sul.

\section{RESULTS}

Overall 18 species and 1,733 adult carabid individuals were sampled. The highest total abundance occurred in the primary forest (747 individuals) and the lowest for Pinus silviculture (355). Secondary forest was intermediate, with 631 exemplars. Galerita lacordarei (Dejean, 1826) was the dominant species in all samples, being responsible for $72 \%$ of the overall abundance.

Rarefaction has shown that species richness follow the same pattern as for abundance: primary forest (14 species), secondary forest (13 species) and Pinus silviculture (10 species) (Fig. 1), but with significant differences only between primary forest and silviculture. There was a significantly higher richness for summer (16 species), and winter (12 species) was significantly richer than spring (Fig. 2). Unfortunately a small number of traps were destroyed or lost along study. Because this, individual-based rarefaction presented has no even lines, despite effort sampling standardized.

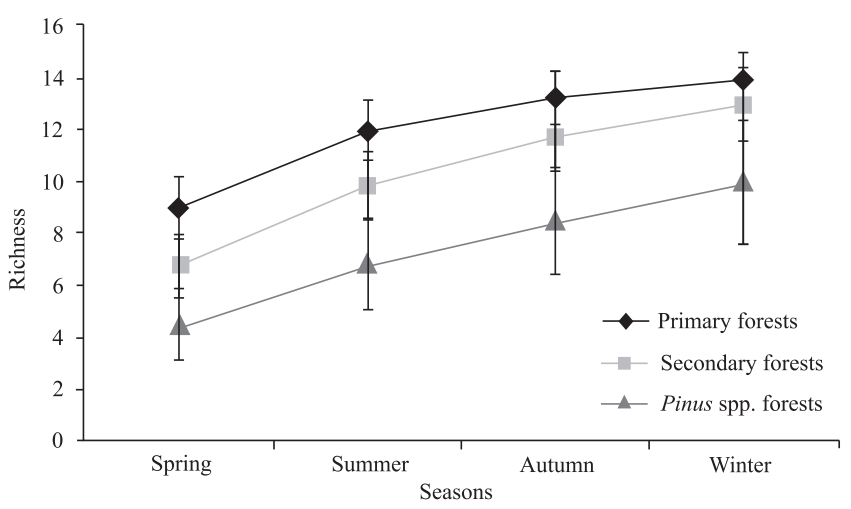

Fig. 1. Sample-based rarefaction (error bars represent 95\% CI) for carabid beetles among environments in São Francisco de Paula, southern Brazil.

The Mantel test did not show significance for the correlation between faunal similarity and distance between sampling sites (Simpson index, correlation $=-0.077 ; \mathrm{p}=0.655$; Morisita index, correlation $=-0.136 ; \mathrm{p}=0.761)$. Thus, transects in the areas were used as the scale for the analyses $(\mathrm{n}=4$, two transects in two replicates for each environment).

There were significant differences among environments for abundance (MANOVA $\mathrm{F}_{2,152}=17.577 ; \mathrm{p}<0.001$ ) and species richness $\left(\mathrm{F}_{2,152}=37.482 ; \mathrm{p}<0.001\right)$, however, there was not for equitability $\left(\mathrm{F}_{2,152}=2.208 ; \mathrm{p}=0.113\right)$ (Fig. 3).

Seven species are common to all environments (Fig. 4). There were significant differences in composition both for

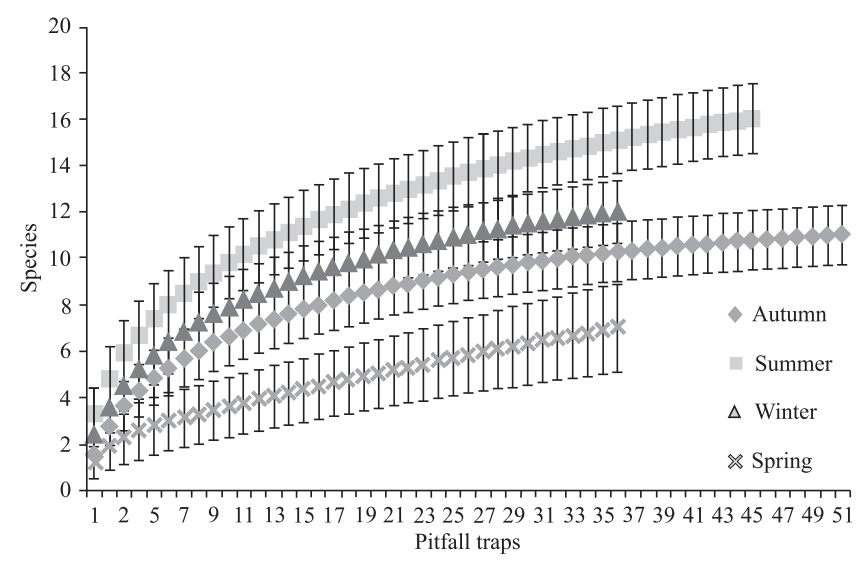

Fig. 2. Individual-based rarefaction (bars are 95\% CI) for carabid beetles among seasons, in São Francisco de Paula, southern Brazil.

environments (ANOSIM Simpson; $\mathrm{R}=0.035 ; \mathrm{p}=0.0001$; Bray-Curtis; $\mathrm{R}=0.070 ; \mathrm{p}<0.0001)$ and for seasons (Simpson $\mathrm{R}=0.122, \mathrm{p}<0.0001$; Bray-Curtis, $\mathrm{R}=0.196$, $\mathrm{p}<0.0001)$. The significant differences were between spring and summer, as well as winter differing from all other seasons (Table I).

Table I. Analysis of similarity (ANOSIM) for Bray-Curtis (lower triangle) and Simpson (upper triangle) among environments for the carabid fauna, in São Francisco de Paula, southern Brazil. Transects ARA and ARB = primary forest, NEB and SEC = secondary forest, PIN and PIL = silviculture with Pinus spp. A significant value $(*)$ means that the carabid fauna between the two compared environments are distinct.

\begin{tabular}{lcccccc}
\hline & ARA & ARB & NEB & SEC & PIN & PIL \\
\hline ARA & - & $0.0042 *$ & 0.0081 & 0 & $0.0004^{*}$ & $0.0010^{*}$ \\
ARB & 0.06 & - & 0.5324 & 0.2256 & 0.8392 & 0.1342 \\
NEB & 0.13 & 0.1800 & - & 0.2248 & 0.3737 & 0.0973 \\
SEC & 0 & 0.3900 & $0.0500^{*}$ & - & 0.7562 & $0.0194^{*}$ \\
PIN & 0 & 0.2000 & $0.0100^{*}$ & 0.5000 & - & 0.2348 \\
PIL & 0 & 0 & 0 & $0.0100^{*}$ & $0.0300^{*}$ & - \\
\hline
\end{tabular}

Among the abiotic data there was significant influence only for temperature on species richness, for all environments, and on abundance, but only for primary and secondary areas (Table II; Figs. 5-6). A visual inspection of the regression indicates that species richness in the primary environment was larger than expected for the observed temperatures.

Table II. Analysis of similarity (ANOSIM) for Bray-Curtis (lower triangle) and Simpson (upper triangle) among climatic seasons for the carabid fauna, in São Francisco de Paula, southern Brazil. A significant value (*) means that the carabid fauna between the two compared seasons are distinct.

\begin{tabular}{lcclc}
\hline & Autumn & Summer & Spring & Winter \\
\hline Autumn & - & 0.9708 & 0.2602 & 0 \\
Summer & 0.3434 & - & 0 & 0 \\
Spring & 0.1533 & $0.0039^{*}$ & - & 0 \\
Winter & 0 & 0 & 0 & - \\
\hline
\end{tabular}



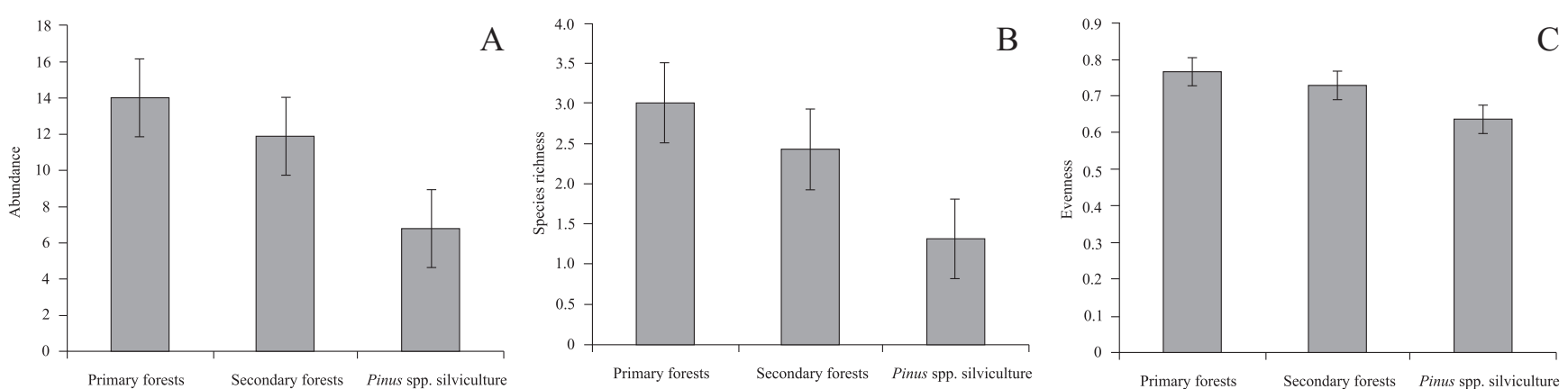

Fig. 3. Carabid fauna among environments in São Francisco de Paula, southern Brazil (error bars represent 95\% CI). A- abundance, B- species richness and $\mathrm{C}$ - equitability.

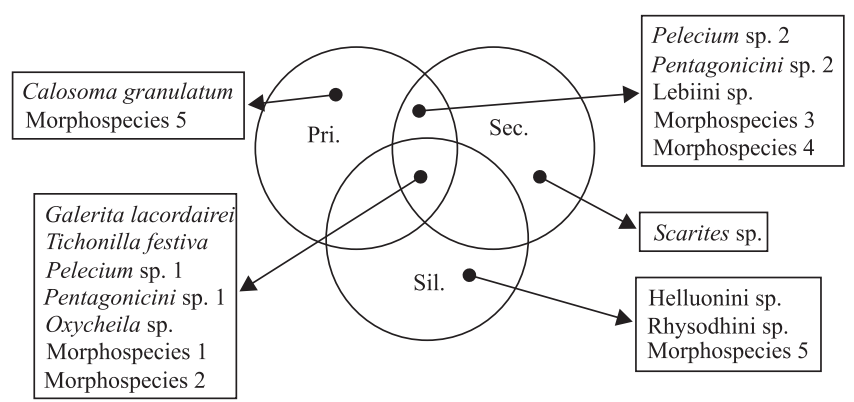

Fig. 4. Species distribution among environments for carabid beetles in São Francisco de Paula, southern Brazil. Pri.: primary forests; Sec.: secondary forests; Sil.: silviculture with Pinus spp.

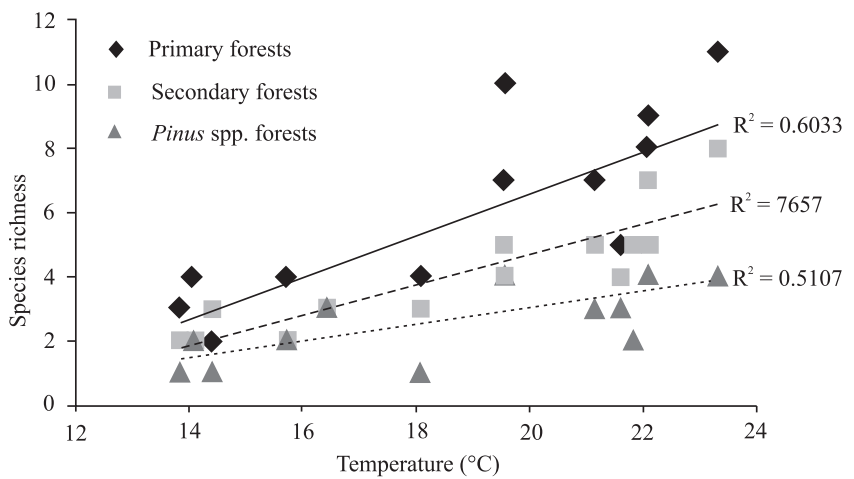

Fig. 5. Regression between temperature and species richness for each environment in São Francisco de Paula, southern Brazil.

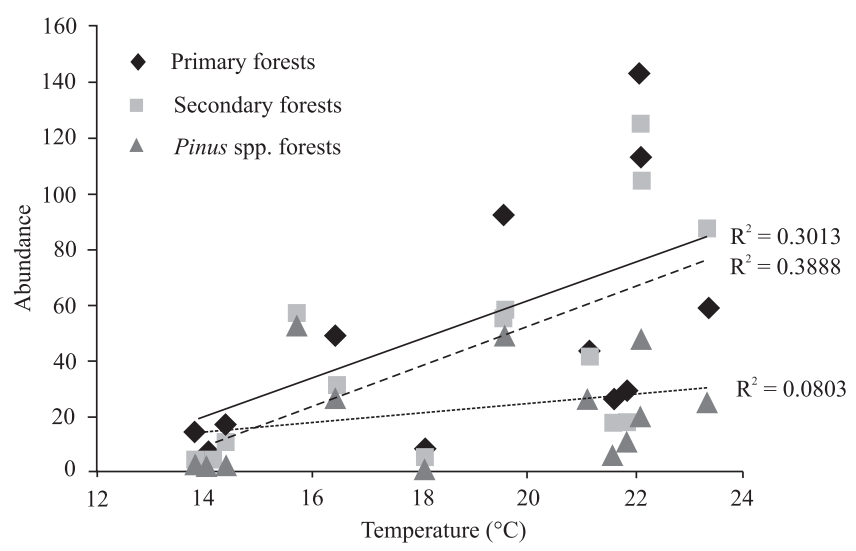

Fig. 6. Regression between temperature and species abundance for each environment in São Francisco de Paula, southern Brazil.

\section{DISCUSSION}

Both richness and abundance followed the expected disturbance gradient: a decrease as disturbance increased. Thus, different aspects of species diversity suggest that soil carabid assemblages are distinct among environments. Causes for this distinction are probably associated to floristic composition and vegetation structure (and consequently, litter composition and structure) between the chosen environments. These factors in their turn can affect local temperature and humidity, determining feeding resources and microhabitat availability (Barbosa et al. 2002). Our results are thus in accordance both with the disturbance response given by carabids and the response they give to habitat structure (Ganho \& Marinoni 2006).

Previous works also compared carabid diversity between preserved and disturbed environments (Uehara-Prado et al. 2009; Silva et al. 2008; Weller \& Ganzhorn 2004), although, as here, few of them actually evaluated a gamut of habitat variables to help identify causes behind those differences in richness and abundance (Tyler 2008; Magura et al. 2003).

Although carabid richness and abundance are known to be higher for undisturbed environments (Fujita et al. 2008; Magura et al. 2002), both Uehara-Prado et al. (2009) and Fernández \& Costas (2004) observed higher abundance in disturbed areas. Our results do not show this increase in abundance with disturbance. It is possible that this difference is related to the kind of disturbance present: Uehara-Prado et al. (2009) worked with areas of Atlantic forest previously logged and burned down, transformed to pastures. They were thus open areas, not closed canopy forests as was silviculture here; open habitats perhaps can allow or induce a higher dispersal of carabids.

Silva et al. (2008) evaluated carabid diversity in disturbed areas under a Mediterranean climate, identifying the most degraded environment (agriculture field under intense management) as the richer in species and showing highest abundance. This was probably due to opportunist and/or generalist species again using open spaces (sparse vegetation leading to higher mobility) and new and constant microclimatic conditions created. Also the studied region has approximately 3,000 years of intense use for agriculture, where carabid assemblages could even show patterns of evolutionary adaptation to these conditions. 
Environmental structure can define resource availability for predatory arthropods. Baldissera et al. (2008) compared spider diversity in the shrub layer of exotic silviculture of Pinus ellioti and Eucalyptus sp. and natural forests of Araucaria angustifolia, indicating the influence habitat structure can have on predators since a higher diversity was found for Eucalyptus sp. areas, not the less disturbed one, but the one with more complex vegetation structure at the shrub level. Further studies on the soil carabid fauna in the Neotropical region have much to gain from analyzing environmental variables associated with litter and soil structure and heterogeneity.

Apart from richness and abundance, the main effects of disturbance on the carabid fauna have been reported by Fujita et al. (2008) as: changes in specific composition, loss of large species and those with lower dispersal abilities besides invasion of species from neighboring areas. A change in species composition is a recurring observation (Uehara-Prado et al. 2009; Latty et al. 2006), since the group has a high sensibility to environmental changes in general (Scott \& Anderson 2003), including canopy species (Lucky et al. 2002; Erwin et al. 2005). It is exactly this characteristic of carabids that render them good bioindicators, and it shows up in our subtropical Neotropical data.

The management associated with reforestation using exotic species (cutting natives to open space for planted trees) alters the carabid fauna (Magura et al. 2003). In pine plantations in Europe, one of the first consequences is the disappearance or drastic reduction in abundance of carabids specialised to those forest conditions. The new open habitats are thus occupied by opportunist species from any adjacent fields; these species were responsible for high richness and abundance levels found by Tyler (2008) in silviculture areas. These carabids, however, would also tend to disappear as the canopy expands and closes decreasing light incidence on the soil surface. Generalist species are expected to persist, however forest specialists would not return. In our case it seems to differ somehow, since G. lacordarei is the dominant species in all environments, regardless of the disturbance and management history. The equitability in Pinus areas seems to be higher, perhaps indicating G. lacordarei as a better competitor in that situation. However this is not substantiated by the statistical analysis.

The loss of large species is related to a cascade of factors, resulting in initial dispersion when faced with management radically changing the environment, and incapacity to return and/or find adequate resources once planted trees grow (Tyler 2008; Magura et al. 2003; Magura et al. 2002). However, in our case, again G. lacordarei is a large species, dominating all areas including those under silviculture. It is clearly a generalist species (Thiele 1977), with high mobility (as inferred from leg size) and probably well adapted to prevailing local factors. Apparently, resources needed for this species are homogeneously distributed (Thiele 1977) and/or unknown factors are causing this. It seems probable that $G$. lacordarei is very generalist and maybe also a good competitor in this assemblage.
The relatively high carabid diversity and G. lacordarei dominance in Pinus silviculture areas can alternatively be attributed to its age ( $\sim 30$ years since planting). This has led to the formation of a well developed (for Pinus areas in this region) shrub layer, increasing both overall environmental heterogeneity and litter diversity. Magura et al. (2003), on the other hand, described a low carabid diversity in exotic plantations in Hungary, even after longer periods (50 years).

Barbosa et al. (2002) suggest that beetle species exhibit specificity towards microhabitats and thus have spatial preferences, which could be only indirectly inferred from local abundance. Certainly the species found in pine silviculture were previously present in neighboring areas, those able to colonize that habitat, as suggested in the similar system explored by Magura et al. (2002). This is in accordance with Tonhasca (1994) as well: more disturbed environments would have less resources and less complex microhabitat structure, which would support less species but perhaps more individuals of generalist and/or opportunistic species.

A recurring difficulty in community studies involving carabids is how confident one can be that the recorded species is closely associated with that specific local assemblage (Desender 1996). This hurdle is sometimes relegated and sometimes considered in detail in the literature. Authors relegating this question to secondary status consider all species sampled as local, assuming that some species would have low abundances, being naturally rare. Authors concerned with this question apply more or less random limits to which species to consider (Desender 1996, see also Hartley et al. 2007). Biological knowledge can sometimes help disentangle this question, even though we would rarely know details about the Neotropical species. Pentagonicini sp.1 and sp.2, Lebiini sp., Rhysodhini sp. and Helluonini sp. could be considered vagrant species in this system, that is, species captured accidentally whilst in a transitory environment, perhaps moving in search of resources (Vieira 2008; Tonhasca 1994). The two first morphospecies are described as arboreal and the others as associated to fallen and/or rotting logs (as for the characteristics of the tribe, Reichardt 1977).

Dominance values for both disturbed and more preserved assemblages in our work are high, with G. lacordarei totalling $72 \%$ of all carabids sampled. It is known that few species tend to numerically dominate carabid assemblages. For example, Latty et al. (2006) reported $61 \%$ of all individuals belonging to four common species in logged areas. Silva et al. (2008) also found a single dominant species of carabid in a survey in areas under silviculture with for exotic Eucalyptus. Invasive carabid species can also be highly dominant as found by Hartley et al. (2007), with Pterostichus melanarius (Illiger, 1798) responsible for $80 \%$ of all individuals, followed by a rich but underrepresented native fauna. Unfortunately, there seems to be no specific studies focusing on the effects that dominant species have on the assemblage. Possibly, G. lacordarei reduces the available stock of resources for other species. If feeding items are rarer, probably more dispersal is required for other carabids, as suggested by Paarmann et al. (2002). 
Winter is relatively rich in species, losing in richness only to summer (Fig. 2). This richness in winter can be attributed to an increase in dispersal by carabids, responding to a food shortage (mainly the dominant herbivores). A higher mobility would lead to high captures by the pitfalls. Different abiotic factors can thus influence the activity of carabid beetles and associated taxa in different climates. Among these factors, temperature had a strong influence on richness, contrary to what Paarmann et al. (1998) found, in which rainfall was decisive for variation in the assemblages of cicindeline beetles in the Amazon. This sort of difference has been attributed to the affinity and adaptation by local species to their habitats (Erwin et al. 2005). Soil humidity is reported as an important characteristic for carabid beetles (Lövei \& Sunderland 1996), but our results do not show any relation to rainfall (Table III). Either this assemblage responds to humidity in a subtler way, or else the constant rainfall in this region never leads to low levels of soil humidity (especially in areas covered by forests).

Table III. Multiple regressions between abiotic factors (temperature and rainfall) and diversity variables (species richness and abundance) of the carabid fauna for each studied environment in São Francisco de Paula, southern Brazil. Significant differences are marked with asterisks.

\begin{tabular}{lllrllc}
\hline \multirow{2}{*}{ Environments } & \multirow{2}{*}{$\begin{array}{c}\text { Diversity } \\
\text { variable }\end{array}$} & $\mathrm{R}^{2}$ & $\mathrm{~F}_{2,10}$ & & \multicolumn{2}{c}{$\mathrm{p}$ value } \\
\cline { 5 - 7 } Primary forest & richness & 0.601 & 7.526 & $0.004^{*}$ & 0.560 \\
& abundance & 0.383 & 3.107 & $0.032^{*}$ & 0.302 \\
Secondary forest & richness & 0.781 & 17.810 & $<0.001^{*}$ & 0.575 \\
& abundance & 0.482 & 4.658 & $0.012^{*}$ & 0.247 \\
Pinus spp. silviculture & richness & 0.578 & 6.843 & $0.009^{*}$ & 0.696 \\
& abundance & 0.317 & 2.318 & 0.072 & 0.173 \\
\hline
\end{tabular}

As a region of relatively low temperatures because of altitude (Jungblut \& Pinto 1997), carabid beetles in the studied area can be expected to be sensitive to temperature and optimally use moments of resource increment, perhaps avoiding unfavourable situations. Thus temperature might influence richness and abundance by an increased mobility of most species during times of favourable conditions.

The influence temperature has on richness in the present work can indicate species dispersal from other areas, or else, a fast development of carabids from the pre-adult stages (Thiele 1977). Long periods of favourable temperatures might contribute to this population increase, whilst short periods may favour individual activity (Diefenbach \& Becker 1992a).

Tyler (2008) suggested that carabid phenology could differ between successional stages. The reverse could be expected, if one interprets succession as a gradual increment in habitat complexity. Disturbances reducing habitat complexity could influence carabid species phenology in the same way. Clark et al. (1997) generalise in stating that carabids hibernating as adults would be favored in mechanically disturbed environments, as in agriculture. Formations with climax vegetation (i.e., not submitted to strong disturbances) would favour species hibernating as larvae, since microhabitat conditions would be more stable (Magura et al. 2002).

Habitat structure can affect the way generalist predators find and hunt their prey. Analysing the spider fauna from the same pitfall trapping samples of the present study, Ott (2004) found differences in spider abundance only between silviculture areas and the other two types of forests. As regards spider richness, all three environments were distinct, with primary areas richer than secondary, and those two richer than silviculture. Although these are different groups of predatory soil arthropods, with potentially many shared prey, both resource and resource use might differ qualitative and quantitatively. Whilst spiders can be grouped in rather clear resource exploration guilds, Neotropical soil carabid species are virtually unknown in terms of resource use. For some groups, what seems to be important for functional distinction among species is: (1) division of prey, with relative specialisation (Straneo \& Ball 1989; Erwin \& Erwin 1976), (2) the inclusion of frugivory, (Marinoni et al. 2001; Paarmann et al. 2001), (3) shared exploration of environmental characteristics (Schreiner \& Irmler 2009) and of the leaf litter (Loreau 1987), (4) differing biotic and abiotic requirements for reproduction (Thiele 1977).

\section{REFERENCES}

Adis, J., Paarmann, W. \& Erwin, T.L. 1986. On the natural history and ecology of small terrestrial ground-beetles (Col.: Bembidiini: Tachyina: Polyderis) from an Amazonian black-water inundation forest, p. 413427. In: den Boer, P.J., Luff, M. L., Mossakowski, D. \& Weber, F. (eds). Carabid beetles: Their adaptations and dynamics. Stuttgart, New York, G. Fischer, 551 p.

Adis, J., Paarmann, W. \& Höfer, H. 1990. On phenology and life-cycle of Scarites (Scaritini, Carabidae) from Central Amazonian floodplains. p. 269-275. In: Stork, N. E. (ed.). The role of ground beetles in ecological and environmental studies. Intercept, Andover, $424 \mathrm{p}$.

Adis, J., Amorim, M.A., Erwin, T.L. \& Bauer, T. 1997. On ecology, life history and survival strategies of a wing-dimorphic ground beetle (Col.: Carabidae: Odacanthini: Colliuris) inhabiting Central Amazonian inundation forests. Studies on Neotropical Fauna and Environment 32:174-192.

Arndt, E., Beutel, R.G. \& Will, K. 2005. Carabidae Latreille, 1802. p.119146. In: Beutel, R. G. \& Leschen, R.A.B. (eds). Handbook of Zoology, Arthropoda, Insecta, Coleoptera, Vol. IV. Berlin, Walter de Gruyter, $567 \mathrm{p}$.

Baldissera, R., Ganade, G., Brescovit, A. \& Hartz, S.M. 2008. Landscape mosaic of Araucaria forest and forest monocultures influencing understorey spider assemblages in southern Brazil. Austral Ecology 33: 45-54.

Ball, G. 1996. Vignettes of the history of neotropical carabidology. Annales Zoologici Fennici 33: 5-16.

Barbosa, M.G.V., Fonseca, C.R.V., Hammond, P.M. \& Stork, N.E. 2002. Diversidade e similaridade entre habitats com base na serrapilheira de uma floresta de terra firme na Amazônia Central. Monografías Tercer Milenio 2: 69-83.

Bohac, J. 1999. Staphylinid beetles as bioindicadtors. Agriculture, Ecosystems and Enviroment 74: 357-372.

Boivin, G. \& Hance, T. 2002. Ground beetle assemblages in cultivated organic soil and adjacent habitats: temporal dynamics of microspatial changes. Pedobiologica 47: 193-202.

Bouchard, P., Grebennikov, V.V., Smith, A.B.T. \& Douglas, H. 2009. Biodiversity of Coleoptera. p. 265-302. In: Foottit, R. G. \& Adler, P. H. (eds.). Insect Biodiversity: science and society. Oxford, Blackwell, 468 p. 
Brown, K.S., Jr. 1997. Diversity, disturbance, and sustainable use of Neotropical forests: insects as indicators for conservation monitoring. Journal of Insect Conservation 1: 25-42.

Butterfield, J. 1997. Carabid community sucession during a forestry cycle in conifer plantations. Ecography 20: 614-625.

Clark, M.S., Gage, S.H. \& Spence, J.R. 1997. Habitats and management associated with common ground beetles (Coleoptera, Carabidae) in a Michigan agricultural landscape. Enviromental Entomology 26: 519 527.

Desender, K. 1996. Diversity and dynamics of coastal dune carabids. Annales Zoologici Fennici 33: 65-75

Desender, K., Maelfait, J. \& Baert, L. 1991. Carabid beetles as ecological indicators in dune management (Coleoptera: Carabidae). Elytron 5: 239-247.

Diefenbach, L.M.G. \& Becker, M. 1992a. Carabid taxocenes of an urban park in subtropical Brazil: I. specific composition, seasonality and constancy (Insecta: Coleoptera: Carabidae). Studies on Neotropical Fauna and Environment 27: 169-187.

Diefenbach, L.M.G. \& Becker, M. 1992b. Carabid taxocenes of an urban park in subtropical Brazil: II. specific diversity and similarity (Insecta: Coleoptera: Carabidae). Studies on Neotropical Fauna and Environment 27: 189-200.

Erwin, T.L. 1990. Natural history of the carabid beetles at the BIOLAT Biological Station, Rio Manu, Pakitza, Peru. Revista Peruana de Entomologia 33: 1-85.

Erwin, T.L. 2000. Arboreal beetles of Neotropical Forests: Agra Fabricius, the Novaurora complex. Smithsonian Contributions to Zoology 608: $1-33$

Erwin, T.L. \& Erwin, L.J.M. 1976. Relationships of predacious beetles to tropical forest wood decay. Part II. The natural history of Eurycoleus macularis Chevrolat (Carabidae:Lebiini) and its implications in the evolution of ectoparasitoidism. Biotropica 8: 215-224.

Erwin, T.L., Pimienta, M.C., Murillo, O.E. \& Aschero, V. 2005. Mapping patterns of $\beta$-Diversity for beetles across the western amazon basin: a preliminary case for improving inventory methods and conservation strategies. Proceedings of the California Academy of Sciences 56: 72-85.

Eyre, M.D., Lott, D.A. \& Garside, A. 1996. Assessing the potential for environmental monitoring using ground beetles (Coleoptera, Carabidae) with riverside and Scottish data. Annales Zoologici Fennici 33: 157-163.

Fernández, M.M.F. \& Costas, J.M.S. 2004. Recolonization of a burnt forest (Pinus pinaster) by Carabidae (Coleoptera). European Journal of Soil Biology 40: 47-53.

Fujita, A., Maeto, K., Kagawa, Y. \& Ito, N. 2008. Effects of forest fragmentation on species richness and composition of ground Beetles (Coleoptera: Carabidae and Brachinidae) in urban landscapes. Entomological Science 11: 39-48.

Ganho, N.G. \& Marinoni, R.C. 2006. A variabilidade espacial das famílias de Coleoptera (Insecta) entre fragmentos de Floresta Ombrófila Mista Montana (Bioma Araucária) e plantação de Pinus elliottii Engelmann, no Parque Ecológico Vivat Floresta, Tijucas do Sul, Paraná, Brasil. Revista Brasileira de Entomologia 23: 1159-1167.

Gotelli, N.J. \& Colwell, R.K. 2001. Quantifying biodiversity: procedures and pitfalls in the measurement and comparison of species richness. Ecology Letters 4: 379-391.

Hammer, Ø., Harper, D.A.T. \& Ryan, P.D. 2001. PAST: Paleontological Statistics Software Package for Education and Data Analysis. Palaeontologia Electronica 4: 1-9. Available at: http://palaeoelectronica.org/2001_1/past/issue1_01.htm (accessed 23 May 2010).

Hartley, D.J., Koivula, M.J., Spence, J.R., Pelletier, R. \& Ball, G.E. 2007. Effects of urbanization on ground assemblages (Coleoptera, Carabidae) of grassland habitats in western Canada. Ecography 30: 673-684.

Holland, J.M. \& Luff, M.L. 2000. The effects of agricultural practices on Carabidae in temperate agroecosystems. Integrated Pest Management Reviews 5: 109-129.

Holtz, A.M., Zanuncio, T.V., Zanuncio, J.C. \& Pratissoli, D. 2001. Coleópteros coletados em plantio de Eucalyptus urophylla na região de Três Marias, Minas Gerais. Revista Floresta 31:1-10.
Humphrey, J.W., Hawes, C., Peace, A.J., Ferris-Kaa, R. \& Jukes, M. R. 1999. Relationships between insect diversity and habitat characteristics in plantation forests. Forest Ecology and Management 113: 11-21.

Ings, T.C. \& Hartley, S.E. 1999. The effect of habitat structure on carabid communities during the regeneration of a native Scottish forest. Forest Ecology and Management 119: 123-136.

Jukes, M.R., Peace, A.J. \& Ferris, R. 2001. Carabid beetle communities associated with coniferous plantations in Britain: the influence of site, ground vegetation and stand structure. Forest Ecology and Management 148: 271-286.

Jungblut, M. \& Pinto, L.F.S. 1997. Levantamentos de solos do centro de pesquisas e conservação da natureza Pró-Mata. Divulgações do Museu de Ciências e Tecnologia UBEA/PUCRS 3: 29-94.

Larsen, K.J. \& Work, T.W. 2003. Differences in ground beetles (Coleoptera: Carabidae) of original and reconstructed tallgrass prairies in northeastern Iowa, USA, and impact of three-year spring burn cycles. Journal of Insect Conservation 7: 153-166.

Latty, E.F., Werner, S.M. Mladenoff, D.J., Raffa, K.F. \& Sickley, T.A. 2006. Response of ground beetles (Carabidae) assemblages to logging history in northern hardwood-hemlock forests. Forest Ecology and Management 222: 335-347.

Lövei, G.L. \& Sunderland, K.D. 1996. Ecology and behavior of ground beetles (Coleoptera, Carabidae). Annual Review of Entomology 41: 231-256.

Lövei, G.L., Magura, T., Tóthmérész, B. \& Ködöböcz, V. 2003. The influence of matrix habitat on ground beetles (Carabidae) species richness patterns in habitat islands, p. 163-172. In: Lövei, G.L. \& Toft, S. (eds.). European Carabidology 2003. Proc. 11th European Carabidologist Meeting. Danish Institute of Agricultural Sciences Report Series No. 114.

Loreau, M. 1987. Vertical distribution of activity of carabid beetles in a beech forest floor. Pedobiologia 30: 173-178.

Lucky, A., Erwin, T.L. \& Witman, J.D. 2002. Temporal and spatial diversity and distribution of arboreal Carabidae (Coleoptera) in a western amazonian rain forest. Biotropica 34: 376-386.

Magura, T., Elek, Z. \& Tóthmérész, B. 2002. Impacts of non-native spruce reflorestation on ground beetles. European Journal of Soil Biology 38: 291-295.

Magura, T., Tóthmérész, B. \& Elek, Z. 2003. Diversity and composition of carabids during a forestry cycle. Biodiversity and Conservation 12: 73-85.

Marinoni, R.C. 2001. Os grupos tróficos em Coleoptera. Revista Brasileira de Zoologia 18: 205-224.

Marinoni, R.C., Ganho, N., Monné, M. \& Mermudes, J.R. 2001. Hábitos alimentares em Coleoptera (Insecta). Ribeirão Preto, Holos, 63 p.

Martins, I.C.F., Cividanes, F.J., Barbosa, J.C., Araújo, E.S. \& Haddad, G.Q. 2009. Análise de fauna e flutuação populacional de Carabidae e Staphylinidae (Coleoptera) em sistemas de plantio direto e convencional. Revista Brasileira de Entomologia 53: 432-443.

Melnychuk, N.A., Olfert, O., Youngs, B. \& Gillott, C. 2003. Abundance and diversity of Carabidae (Coleoptera) in different farming systems. Agriculture, Ecosystems \& Environment 95: 69-72.

Moura, L.A. 2007. Coleópteros terrestres. p. 210-229. In: Becker, F.G., Ramos, R.A. \& Moura, L.A. (Orgs). Biodiversidade. Regiões da Lagoa do Casamento e dos Butiazais de Tapes, Planície Costeira do Rio Grande do Sul. Série Biodiversidade 25. Brasília, Ministério do Meio Ambiente, 388 p.

Niemelä, J. 1996. From systematics to conservation- carabidologists do it all. Annales Zoologici Fennici 33: 1-4.

Ott, R. 2004. Aspectos ecológicos da macrofauna de aracnológica de serrapilheira (Aranae, Opiliones, Scorpiones) em áreas de floresta ombrófila mista primária, secundária e em silvicultura de Pinus spp. no Centro de Pesquisa e Conservação da Natureza Pró-Mata, São Francisco de Paula, RS. Ph. D. Dissertation, Graduate Program in Zoology. Porto Alegre, Pontifícia Universidade Católica do Rio Grande do Sul.

Paarmann, W., Adis, J., Lüdecke, K., Tobaschus, N. \& Fonseca, C.R.V. 1998. Spatial and temporal distribution of a tiger beetle guild (Coleoptera; Carabidae; Cicindelinae) along a 105m long transect in the Reserva Flo- 
restal A. Ducke near Manaus (Central Amazonia). Acta Amazonica 28: 331-344.

Paarmann, W., Adis, J., Stork, N., Gutzmann, B., Stumpe, P., Staritz, B., Bolte, H., Küpers, S., Holskamp, K., Niers, C. \& Fonseca, C.R.V. 2001. The structure of ground beetles assemblages (Coleoptera: Carabidae) at fig fruit falls (Moraceae) in a terra firme rain forest near Manaus (Brazil). Journal of Tropical Ecology 17: 549-561.

Paarmann, W., Gutzmann, B., Stumpe, P., Bolte, H., Küppers, S., Holzkamp, K., Niers, C., Adis, J., Stork, N.E. \& Fonseca, C.R.V. 2002. The structure of ground beetle assemblages (Coleoptera: Carabidae) at fruit falls of Melastomataceae trees in a Brazilian terra firme rain forest. Biotropica 34: 368-375.

Penev, L. 1996. Large-scale variation in carabid assemblages, with special reference to the local fauna concept. Annales Zoologici Fennici 33: 49-63.

Rainio, J. \& Niemelä, J. 2003. Ground beetles (Coleoptera: Carabidae) as bioindicators. Biodiversity and Conservation 12: 487-506.

Reichardt, H. 1967. A monographic revision of the American Galeritini (Coleoptera, Carabidae). Arquivos de Zoologia 15: 1-176.

Reichardt, H. 1977. A synopsis of the genera of Neotropical Carabidae (Insecta, Coleoptera). Quaestiones Entomologicae 13: 346-493.

Reichardt, H. 1979. The South American carabid fauna: endemic tribes and tribes with African relationships, p. 319-325. In: Erwin, T.L., Ball, G.E. \& Whitehead, D.R. (eds.). Carabid Beetles: Their Evolution, Natural History, and Classification. The Hague, Dr. W. Junk, 635 p.

Roig-Juñent, S. 1998. Carabidae. p. 194-210. In: Morrone, J.J. \& Coscarón, S. Biodiversidad de artrópodos argentinos. La Plata, Ediciones SUR, 599 p.

Schreiner, R. \& Irmler, U. 2009. Niche differentiation and preferences of Elaphrus cupreus Duftschmid, 1812 and Elaphrus uliginosus (Fabricius, 1792) (Coleoptera: Carabidae) as reason for their different endangerment in Central Europe. Journal of Insect Conservation 13: 193-202.

Silva, P.M., Aguiar, C.A.S., Niemelä, J., Souza, J.P. \& Serrano, A.R.M. 2008. Diversity patterns of ground-beetles (Coleoptera: Carabidae) along a gradient of land-use disturbance. Agriculture, Ecosystems and Enviroment 124: 270-274

Scott, W.A. \& Anderson, R. 2003. Temporal and spatial variation in carabid assemblages from the United Kingdom environmental change network. Biological Conservation 110: $197-210$
Soares, M.I.J. \& Costa, E.C. 2001. Fauna do solo em áreas com Eucalyptus spp. e Pinus elliottii, Santa Maria, RS. Ciência Florestal 11: 29-43.

Straneo, S.L. \& Ball, G.E. 1989. Synopsis of the genera and subgenera of the tribe Peleciini, and revision of the Neotropical and Oriental species (Coleoptera: Carabidae). Insecta Mundi 3: 73-178.

Taylor, R.J. \& Dorann, N. 2001. Use of invertebrates as indicators of the ecological sustainability of management under the Montreal process. Journal of Insect Conservation 5: 221-231.

Thiele, H.U. 1977. Carabid beetles in their environments: A study on habitat selection by adaptations in physiology and behavior. Stuttgart, Springer, 369 p.

Thomas, C.F.G., Brown, N J. \& Kendall, D A. 2006. Carabid movement and vegetation density: implications for interpreting pitfall trap data from split-field trials. Agriculture, Ecosystems and Enviroment 113: 51-61.

Tonhasca Jr., A. 1994. Diversity indices in the analysis of biological communities. Ciência e Cultura 46: 138-140.

Triplehorn, C.A. \& Johnson, N.F. 2005. Borror and DeLong's introduction to the study of insects. $7^{\mathrm{a}} \mathrm{ed}$., Belmont, Thomson Brooks/Cole, $864 \mathrm{p}$.

Tyler, G. 2008. The ground beetle fauna (Coleoptera; Carabidae) of abandoned fields, as related to plant cover, previous management and sucession stage. Biodiversity and Conservation 17: 155-172.

Uehara-Prado, M., Fernandes, J.O., Bello, A.M., Machado, G., Santos, A.J., Vaz-de-Mello, F.Z. \& Freitas, A.V.L. 2009. Selecting terrestrial arthropods of indicators of small-scale distrbance: A first approach in the Brazillian Atlantic Forest. Biological Conservation 142: 12201228 .

Vieira, L.M. 2008. Estrutura de comunidade de Carabidae (Coleoptera) em capões das sub-regiões Miranda e Abobral do pantanal sul matogrossense. Iheringia, Zoologia, 98: 317-324.

Weller, B. \& Ganzhorn, J.U. 2004. Carabid beetle community composition, body size, and fluctuating asymmetry along an urban-rural gradient. Basic and Applied Ecology 5: 193-201.

Werner, S.M. \& Raffa, K.F. 2000. Effects of forest management practices on the diversity of ground-occurring beetles in mixed northern hardwood forests of the Great Lakes Region. Forest Ecology and Management 139: 135-155. 